\title{
Application of Radial Heat Pipe to Heat Recovery of Flue Gas
}

\author{
Gongduo Zhang , Shun Li , Hui Jiang , Guowei Xie \\ Sinosteel Anshan Research Institute of Thermo-energy Co., LTD., Anshan, Liaoning, 114044, \\ China \\ Asrnls2008@126.com
}

Keywords: coke oven, energy saving, radial heat pipe, flue-gas.

Abstract. According to the heat balance of coke oven, the key to energy saving of coking industry was made clear. The technology of flue-gas heat recovery with radial heat pipe was introduced. Then its advancement was described. By giving an example, the application of radial heat pipe in coke-oven proved that the technology obtained obvious economic and social benefits, which also has practical value and popularizing prospect.

\section{Introduction}

Coking enterprise is indispensable to iron and steel production, plays an important role in the construction of modernization. Meanwhile it consumes large energy, which energy cost takes very heavy proportion in total products. Therefore, saving energy and reducing consumption of coking enterprise is especially important.

Thermal balance for JN43 coke oven was tested. The result was as follows:

Table 1 Thermal balance for JN43 coke oven

\begin{tabular}{|c|c|c|c|c|c|c|c|}
\hline \multicolumn{4}{|c|}{ heat income } & \multicolumn{4}{|c|}{ Heat expenditure } \\
\hline $\begin{array}{c}\text { serial } \\
\text { number }\end{array}$ & item & $\begin{array}{l}\text { heat } \\
/(\mathrm{kJ} / \mathrm{t})\end{array}$ & percentage & $\begin{array}{c}\text { serial } \\
\text { number }\end{array}$ & item & $\begin{array}{l}\text { heat } \\
/(\mathrm{kJ} / \mathrm{t})\end{array}$ & percentage \\
\hline $\mathrm{Q}_{1}$ & $\begin{array}{c}\text { heating gas } \\
\text { physical thermal }\end{array}$ & 9700 & 0.3 & $\mathrm{Q}_{1}{ }^{\prime}$ & sensible heat of coke & 1192754 & 37.15 \\
\hline $\mathrm{Q}_{2}$ & $\begin{array}{l}\text { combustion air } \\
\text { physical thermal }\end{array}$ & 55212 & 1.72 & $\mathrm{Q}_{2}{ }^{\prime}$ & $\begin{array}{l}\text { sensible heat of crude } \\
\text { gas }\end{array}$ & 488530 & 15.21 \\
\hline $\mathrm{Q}_{3}$ & $\begin{array}{l}\text { charging coal } \\
\text { physical thermal }\end{array}$ & 39072 & 1.22 & $\mathrm{Q}_{3}{ }^{\prime}$ & $\begin{array}{l}\text { latent and sensible } \\
\text { heatof water vapor }\end{array}$ & 549530 & 17.12 \\
\hline $\mathrm{Q}_{4}$ & $\begin{array}{l}\text { heating gas } \\
\text { combustion heat }\end{array}$ & 2848112 & 88.72 & $\mathrm{Q}_{4}{ }^{\prime}$ & $\begin{array}{l}\text { latent and sensible heat } \\
\text { of tar }\end{array}$ & 90201 & 2.81 \\
\hline \multirow[t]{7}{*}{$\mathrm{Q}_{5}$} & $\begin{array}{l}\text { leak crude gas } \\
\text { combustion heat }\end{array}$ & 258163 & 8.04 & $\mathrm{Q}_{5}{ }^{\prime}$ & $\begin{array}{c}\text { latent and sensible } \\
\text { heatof crude benzene }\end{array}$ & 21719 & 0.68 \\
\hline & & & & $\mathrm{Q}_{6}{ }^{\prime}$ & $\begin{array}{c}\text { sensible heat of } \\
\text { ammonia }\end{array}$ & 5149 & 0.16 \\
\hline & & & & $\mathrm{Q}_{7}{ }^{\prime}$ & sensible heat of flue gas & 555608 & 17.31 \\
\hline & & & & $\mathrm{Q}_{8}{ }^{\prime}$ & $\begin{array}{c}\text { Gas loss of } \\
\text { commutation progress }\end{array}$ & & \\
\hline & & & & $\mathrm{Q}_{9}{ }^{\prime}$ & $\begin{array}{c}\text { furnace surface heat } \\
\text { dispersion }\end{array}$ & 273136 & 8.54 \\
\hline & & & & $\mathrm{Q}_{10}{ }^{\prime}$ & other thermal loss & 33632 & 1.05 \\
\hline & & & & & total & 3210259 & 100 \\
\hline
\end{tabular}

According to table 1 sensible heat of coke, heat crude gas and flue gas respectively is $37.15 \%$, $15.21 \%$ and $17.31 \%$, so the three parts heat should be the main objects energy saving and waste heat utilization in coking industry.

Sensible heat of coke is recovered by coke dry quenching, which is mature and applied both at home and abroad. Because of tar condensation and inefficient heat-exchanger the standpipe waste heat recovery from crude gas and chemical products cannot be spread ${ }^{[1-3]}$. Moreover, on account of 
complex structure, overall large equipment, tube explosion, and high manufacturing costs the sensible heat technology from flue gas is also not widely used.

\section{Flue Gas Heat Recovery Technology}

Coke is the main raw materials for ironmaking. In coke process flue gas produced by coke oven gas and blast furnace gas after combustion is vented directly in a lot of companies, which not only wastes energy, also pollutes the environment $250^{\circ} \mathrm{C} \sim 320^{\circ} \mathrm{C}$ flue gas waste heat is recovered by the heat pipe heat-exchanger to produce steam, to replace the original steam boiler and to reduce the cost of steam. So it was a new energy saving and environmental technology.

The conventional axial heat pipe was applied to heat recovery from coke oven flue gas, whose main technical characteristics are showed in table 2.

Table 2 Advantages and disadvantages of axial heat pipe

\begin{tabular}{|c|c|}
\hline advantages of axial heat pipe & disadvantages of axial heat pipe \\
\hline efficient superconductor equipment & complex structure \\
\hline excellent isothermal homeothermia & Huge equipment \\
\hline $\begin{array}{c}\text { excellent unidirectional thermal-transfer } \\
\text { characteristics }\end{array}$ & Easy tube explosion' \\
\hline good environmental adaptability & damageing irreversibility \\
\hline avoid dew point corrosion & relatively high equipment cost \\
\hline
\end{tabular}

In view of the advantages and disadvantages of the axial heat pipe and advantage of the axial heat pipe a new radial heat pipe heat-exchanger was designed.

The advantages and disadvantages of new radial heat pipe heat-exchanger are shown in table 3:

Table 3 Advantages and disadvantagesof radial heat pipe

\begin{tabular}{|c|c|}
\hline advantages of radial heat pipe & disadvantages \\
\hline efficient superconductor equipment) & high slightly superconductor cost \\
\hline excellent isothermal homeothermia & \\
\hline $\begin{array}{c}\text { Excellent unidirectional thermal- transfer } \\
\text { characteristics }\end{array}$ & \\
\hline good environmental adaptability & \\
\hline avoid dew point corrosion & \\
\hline decreased equipment cost & \\
\hline simple heat-exchanger & \\
\hline high efficiency after damaging pipe & \\
\hline
\end{tabular}

The manufacturing cost of radial heat pipe is higher than that of axial heat pipe slightly,but due to reducing heat-exchanger fluid casing and two stages, the complexity and cost greatly reduced, which greatly improved the economic benefits. It overcomed loss of the total area after the damage, at the same time kept all the advantages of the axial heat pipe heat-exchanger.

\section{Advanced Performance of Eccentric Radial Heat Pipe}

New eccentric radial heat pipe developed had advanced performances as the following:

-Eccentric radial heat pipe heat-exchanger was put forward theoretically and applied to project practice successfully, which was a first one developed in the world.

- According to the existing problem of the axial heat pipe heat-exchanger at home and abroad, the technology effectively resolved problems such as complex structure, big steel consumption to steam production, irreversible loss and low thermal efficiency after damaging for the axial heat pipe heat-exchanger.

- The eccentric radial heat pipe heat-exchanger had some advantages of eccentricity scientifically designed and heat pipe working medium increased to achieve a reasonable state of working medium, 
improve the thermal efficiency of heat pipe heat-exchanger, reduce overall project cost and raise the production efficiency, whose energy-saving efficiency reaches the international advanced level.

- The proprietary online opening is applied to construction process, which makes pressure fluctuation at least and does not delay the normal production.

\section{Application of Radial Heat Pipe}

Eccentric radial heat pipe developed was successfully applied to $4.3 \mathrm{~m}$ coke oven in a domestic company coking plant. The key equipment operation was stable and steam production capacity can meet the requirements, air had not blocking phenomenon, whose pressure control was good in the bottom of the furnace flue. Main equipment adopted whole steel structure, horizontal layout, high drum. Water power for natural circulation can save electricity by centrifugal fan controlled inverter.Heat-exchanger was divided into the evaporator and preheater. Modular design made it easy to manufacture, transport and field construction. According to the different temperature eccentric radial heat pipes were horizontally arranged and formed the tube group to improve heat exchange efficiency and reduce the consumption of steel.

Per ton coke can produce saturated steam $68.8 \mathrm{~kg}$, namely $0.19 \mathrm{GJ} / \mathrm{t}$, in the same period the radial heat pipe consumes only $1.29 \mathrm{kw} / \mathrm{t}$ Practice

\section{Economic and Social Benefits}

The heat recovery project with radial heat pipe was put into application in 2014, the actual economic benefits were shown in the table 4 and table 5:

Table 4 Project income

\begin{tabular}{cccccc}
\hline serial number & item & unit & quantity & unit price (yuan) & $\begin{array}{c}\text { amount of money (million } \\
\text { yuan) }\end{array}$ \\
\cline { 3 - 5 } & saturated steam & ton/a & 64000 & 78 & 499.2 \\
& generated energy & $12800 \mathrm{MW}$ & & 0.4 & 512 \\
\hline
\end{tabular}

Table 5 Project cost

\begin{tabular}{cccccc}
\hline serial number & item & unit & annual waste & $\begin{array}{c}\text { unit price } \\
\text { (yuan) }\end{array}$ & $\begin{array}{c}\text { total annual cost } \\
\text { (million yuan) }\end{array}$ \\
1 & direct material cost & & & & \\
1.1 & desalted water & million tons & 7.04 & 3 & 21.12 \\
1.2 & cooling Water & million tons & 1.6 & 0.4 & 0.64 \\
1.3 & low pressure steam. & million tons & 0.8 & 78 & 62.4 \\
1.4 & medicament expense & tons & & & 1 \\
1.5 & $\begin{array}{c}\text { plant-power } \\
\text { operation and } \\
2\end{array}$ & million $\mathrm{kWh}$ & 135 & 0.7 & 94.5 \\
& & & & 10 \\
\hline
\end{tabular}

Full-year net income: 512-189.66 = 322.34 million.

This technology can fundamentally solve the problem of flue gas direct emissions, at the same time produce saturated steam as a by-product. Through optimization selection and rational structure flue gas heat was recovered at the low cost to reduce steel consumption each ton steam. In addition, for iron and steel enterprises with generating set a superheat can added in the front of the heat-exchanger equipment to raise the quality of the steam. The steam as supplementary can be incorporated into dual pressure generator or back pressure generator. So this technology realized the real meaning of energy 
saving and technical energy reuse, had strong promotion prospects in large integrated iron and steel enterprises.

\section{Reference}

[1] Chun Sun-Jun. Discussion on utilization of delivered heat of coke oven [J]. METALLURGICAL POWER, 2013,158(4):27 34 .

[2] Jiang Shao-You. Application of Evaporated Uptake Cooling System of Coke Oven and Existing Problems [J] Aisc Techniques, 1998,(6):10 15 . .

[3] Yang Shi-Jie,.Yu Hong-Ling, Lin You-Bin,ect.. A method and tests of coke-oven raw gas heat recovery [J]. Energy Research and Information, 2013,29(4):214 217. 